\title{
THE MORPHOGENESIS OF SELECTED LINGUAL PAPILLAE IN OVINE AND PORCINE FOETUSES OBSERVED BY SCANNING ELECTRON MICROSCOPY
}

\author{
F. TICHÝ \\ Department of Anatomy, Histology and Embryology \\ University of Veterinary Science, $61242 \mathrm{Brno}$
}

Received March 25, 1991

\begin{abstract}
Tichý F.: The Morphogenesis of Selected Lingual Papillae in Ovine and Porcine Foetuses Observed by Scanning Electron Microscopy. Acta vet. Brno, 61, 1992: 3-10.
\end{abstract}

The samples of tongues collected from ovine foetuses at 70 and 126 days and from porcine foetuses at 68 and 92 days after fertilization were examined for the stage of morphogenesis in circumvallate, fungiform and filiform papillae. Attention was paid to the degree of differentiation of epithelium of the lingual mucosa, the intensity of keratinization in the superficial layers of the developing papillae, and the presence and formation of gustatory pores on the circumvallate and fungiform papilae.

The circumvallate and fungiform papillae appeared in both species earlier than the other papillary types. The epithelium first attained its definitive appearance on the circumvallate and fungiform papillae. The keratinization of epithelial cells of the lingual mucosa was more marked in the pig than in the sheep.

The localization and appearance of gustatory pores on both the circumvallate and the fungiform papillae were similar in the two species.

Tongue, papillae, epithelium, gustatory pore

The lingual mucosa has been studied thoroughly from all aspects, such as morphology, physiology, pathology, etc., and the reviews of the results and their interpretations are available in the textbooks (Krölling and Grau 1960; Banks 1981; Rooss and Reith 1985, and others). Particular attention has been given to comparative studies of the lingual papillae in the main domestic and farm animal species (Banks 1981; Cormack 1984).

The morphogenesis of several types of lingual papillae has been investigated in both the mammals used in the laboratory (Baratz and Farbman 1975) and those used in farming (Smolich and Michel 1985). The development of lingual papillae, including the process of differentiation of taste buds, has been described in sheep and pigs (Tichý and Cerný 1987; Tichý 1991 a, b).

Variability in appearance of the surface of lingual epithelium in primates and man has been reported by several authors (Takagi et al. 1976: Nair and Sehroeder 1981; Matravers et al. 1982) who have related these considerable differences to the degree of keratinization of the surface epithelial cells. I i da and co-workers (1985) even found differences during the keratinization process of epithelium in one and the same papilla. Farbman (1970) has been interested in keratinization of the surface epithelial cells on filiform papillae of the rat tongue. He observed two populations of epithelial cells, one producing hard and the other soft keratin. His research was followed by that of Miles (1974), Hume and Potten (1976) and Hofer (1981) who all confirmed that differences in the epithelial cell populations depended on the type of keratin produced. Variations in epithelial morphology of the lingual mucosa were associated by some authors with the presence of different protein components in the epithelial cells (Singh et al. 1974, 1980; Baratz and Farbman 1975; Boshell et al. 1980, 1982).

The special presentation of lingual papillae facilitated by scanning electron microscopy well illustrates the differences in arrangement of keratinized epithelial cells in various parts of the papilla (Camaron 1966; Hume and Potten 1976).

The majority of the studies, however, deals with the lingual mucosa in either small laboratory animals, man or primates while the corresponding data on farm animals are insufficient or non-existent. This led us to investigate selected types of lingual papillae in sheep and pigs in order to contribute to the understanding of their development and differentiation. 


\section{Materials and Methods}

The samples were collected from the tongues of ovine foetuses at 70 and 126 days and of porcine foetuses at 68 and 92 days. In each age category three animals were always sampled. Foetal age was estimated on the basis of the crown-rump length (Evans and Sack 1973) and the age categories were chosen according to the results obtained by light microscopy (Tichý and Cerný 1987; Tichý $1991 \mathrm{a}, \mathrm{b}$ ). The lingual tissue for investigation (about $1 \mathrm{~cm}^{3}$ ) was excised from the area at the body-root junction and care was taken to cut equal parts to the right and the left of the median line of the tongue.

The material was immediately washed in 3 consecutive saline baths and fixed in $10 \%$ formaldehyde. Dehydration took place in a graded series of alcohol $(60 \%, 70 \%, 96 \%$ and $100 \%)$ followed by anhydrous acetone.

The fixed samples were dried at the critical point and coated with gold in a Balzers SCD 040 apparatus. They were examined and photographed in a Tesla BS 300 scanning electron microscope.

\section{Results}

Ovine foetus at 70 days (Plate I.)

The dorsum linguae is broken into ridgelike elevations, varying in size and shape, running in the rostral-caudal direction. The elevations increase in height in the aboral direction, i. e., at its caudal end each protrudes as a primitive papilla. From this extends another ridge gradually increasing in height. The most marked unevenness of the surface can be seen on the dorsum linguae in its middle part, while towards the margins of the tongue elevations gradually become lower and smaller. (Fig. 1)

The ridges are separated by depressions of varying depth and size. These are partially filled with detritus resulting from epithelial desquamation which is most noticable on the dorsal surfaces of the ridges. In some areas the superficial layers of epithelium are eroded to a great extent. In the depressions and grooves between the ridges the epithelial surface is markedly less destroyed. (Fig. 1)

At the body-root junction, the side parts of the dorsum linguae show regions with a markedly lower degree of roughness and a flatter and less desquamated epithelial surface than in the other areas. At this stage no bases of circumvallate papillae are yet discernible, nor are there any signs of gustatory pores indicating the presence of differentiating taste buds in the epithelium.

Ovine foetus at 126 days (Plates II. to V.)

The mucosa on the dorsum linguae gives rise to several types of papillae. Of these the circumvallate papillae are the dominant structures in the area of body-root junction. They are situated in two rows along the lateral margins of the tongue, each papilla being encircled by a broad vallum slightly protruding above the level of the surrounding mucosa. Occasionally, circumvallate papillae have a spiral form; in this case they are found in a medial position to the usual papillae (Fig. 2 and 3 ).

Among the circumvallate papillae, the lingual mucosa forms projections, varying in size, which are present either singly or in groups. These are the developing anlages of filiform papillae. Near the median line and rostral to the circumvallate papillae are the fungiform papillae of typical shape. They are surrounded with ridge- or dome-shaped structures, different in both size and appearance, which are separated by depressions and grooves partly filled with cell detritus (Fig. 4).

The surface epithelium of the lingual mucosa is smooth and lacks the areas of eroded epithelium seen in the earlier age category. The superficial epithelial layers 
shed keratinized cells particularly from the walls of differentiating papillae. Apart from cell detritus and desquamated cells, the surface includes small founded bodies, mostly uniform in size and appearance, found at the foot of the developing papillae either singly or in clusters (Fig. 5).

Gustatory pores are formed in the epithelium of the dorsal surfaces on both the fungiform and the circumvallate papillae. The former contains only low numbers of the pores located mostly in the centre of the papillary surface, while on the latter the pores are much more frequent and their distribution in the dorsal epithelium is quite irregular. The openings are often masked by desquamated epithelial cells (Fig. 5).

\section{Porcine foetus at 68 days (Plates VI. to IX.)}

The mucosal surface of the dorsum linguae is broken into a lot of ridges which greatly vary in size and whose course and orientation are completely irregular. From the marked roughness of the lateral parts, the height of elevations gradually decreases towards the median line of the tongue. The depressions, differing in size and depth, between the mucosal ridges are partly filled with detritus resulting from desquamated or eroded epithelial cells (Fig. 6).

The anlages of circumvallate papillae are present in the area of body-root junction. Each of them is bordered with a spacious encircling furrow. The dorsal surface of the developing papilla is structured into ridgelike or bulging elevations varying in size and separated by narrow grooves of different depth. The epithelium on the surface is formed by flat keratinized cells desquamating in large amounts, particularly on the walls of the secondary elevations, and producing the detritus found on the bottoms of depressions and grooves which separate the elevations.

The developing fungiform papillae are situated, mostly in groups, rostral to the anlages of circumvallate papillae on the dorsum linguae. They present as dome-shaped projections only slightly elevated above the level of the surrounding mucosa. Their anlages are made separate by shallow encircling furrows (Fig. 7 and 8).

The epithelium of lingual mucosa covers the developing circumvallate and fungiform papillae in a smooth, compact layer with patches of desquamation. The undifferentiated mucosal structures around the papillae, on the other hand, bear large regions of eroded epithelium. This is most pronounced in the middle area of the dorsum linguae (Fig. 7 and 8).

Gustatory pores are a rare finding on the dorsal surface of the circumvallate papilla anlages. They usually open onto the bottoms of grooves and depressions separating the secondary elevations of the papillary surface. They are present in higher numbers at the border of the dorsal surface and the wall, following the circumference of the papilla; their openings are often found in the middle of the flat keratinized epithelial cells (Fig. 9).

\section{Porcine foetus at 92 days (Plates X. to XIV.)}

The dorsum linguae is structured into fully differentiated circumvallate, fungiform and filiform papillae completed in shape. The circumvallate papilae prevail at the body-root junction. They present as large disc-shaped elevations encircled by a large vallum. Their dorsal surfaces show numerous protrusions, varying in shape, which are separated by deep and differently spacious grooves and furrows filled with desquamated epithelial cells and clusters of light round bodies uniform in appearance (Fig. 11 and 12).

The fungiform papillae are scattered over the lingual surface rostral to the cir- 
cumvallate ones. They appear as dome-shaped structures of different sizes surrounded with a lot of filiform papillae. These are conical in shape and are covered with desquamative keratinized epithelium. The rostral surfaces decline to the papillary bases at a larger angle than do the caudal surfaces. The former surfaces bear thicker layers of keratinized cells than the latter ones (Fig. 14).

In areas lateral and caudal to the circumvallate papillae, the mucosal surface is differentiated into papillae, irregular in shape and size, between which are deep and spacious depressions. The same structures are on the lateral surface of the radix linguae (Fig. 10 and 11 ).

The epithelium of lingual mucosa covers the surfaces of circumvallate and fungiform papillae in a smooth layer in which an occasional unevenness is caused by desquamation. This, however, is a prominent feature in superficial keratinized cells on the filiform papillae (Fig. 12 and 14).

Gustatory pores are formed predominantly on the circumvallate papillae at the border of the dorsal surface and the wall. Occasionally, thes occur also in the middle of the secondary irregularities of the dorsal surface. Their openings are often masked under desquamating epithelium and may even be found in the centre of an intact epithelial cell. Less frequent is their occurrence on the fungiform papillae where they appear along the circumference of the dorsal surface (Fig. 13 and 14).

\section{Discussion}

The ontogenic development of the lingual mucosa, with special emphasis on the morphogenesis of some papillae and the differentiation of taste buds, in sheep and pigs has already been reported in the light microscopic studies (Tichý and Černý 1987; Tichý 1991 a, b).

The data published in sheep (Tichý and Černý 1987) show that the shape of circumvallate papillae begins to differentiate on the tongue with the 60th day of intrauterine development. At this stage, however, the commencing papilla has no effect on the appearance of the mucosal surface because the associated structures, such as the encircling furrow, etc., develop later (at about 85 days). This is in agreement with our findings on the dorsum linguae of the 70-day-old ovine foetus in which no indication of shape differentiation was seen in any of the papillae followed. A question arises of whether the area of body-root junction, with a relatively smooth and even mucosa, is the site of initiation for the restructuring of the dorsum linguae. However, the evidence suggests that this area is the first to show the rudiments of the circumvallate papillae (Tichý and Černý 1987).

The irregular elevations presenting as ridges and vallums on the dorsum linguae in this period are likely to give later rise to the other types of papillae, i.e., filiform, concial and fungiform ones, which begin to take shape between 86 and 93 days of foetal development (Tichý and Černý 1987). The time interval regarded as the period of differentiation of the lingual papillae should be extended on the basis of our observations made with the scanning electron microscope. It was found that as late as at $\mathbf{1 2 6}$ days the tongue of an ovine foetus showed quite atypical elevations most frequently located near the fungiform papillae. Another interesting finding of this period was the presence of unusual spiral-shaped circumvallate papillae situated medial to the typical circumvallate papillae. This aberrant shape could be a result of defective differentiation of a papilla but it may also present an incomplete papilla which will attain its characteristic appearance during further development. 
Some of the studies giving a special image of the lingual surface in various mammalian species (Takagi et al. 1976; Matravers et al. 1982; Iida et al. 1985 and others) have described differences in appearance of the rostral and the caudal surfaces in relation to the degree and development of epithelial keratinization in each papillary type. Our results showed that the surface of a developing ovine lingual papilla was uniform in appearance except for the parts near the papillary base where the degree of unevenness increased due to strong desquamation of keratinized epithelium. Some of the earlier reports (Farbman 1970; Miles 1974; Hofer 1981) mention two types of keratinization which affect the final character of the surface epithelial cells, particularly with respect to the presence of various keratohyaline granules in the cytoplasm (Boshell et al. 1980, 1982, and others). The lingual papillae in a rat foetus even showed a different topography of these cells on the papillary surface (Baratz and Farbman 1975; Singh et al. 1980). We are unable to comment these observations since the process of keratinization in the lingual epithelium was not studied. However, it was found that, in 70-day-old foetuses, the epithelium of the dorsum linguae involved extensive regions of eroded cells which were all repared during the following maturation of the mucosa (till day 126). In our view the epithelium undergoes a qualitative change during this period; the original "primitive" stratified epithelium, especially its surface layers, is gradually shed and replaced with the definitive epithelium. Our earlier light microscopic observations support this opinion (Tichý and Černý 1987; Tichý 1991 a,b).

In sheep, gustatory pores were located on the dorsal surfaces of circumvallate and fungiform papillae at 126 days of foetal development. This is in accord with the findings made earlier in the light microscope (Tichý and Cerný 1987). Close to the openings of pores there were large quantities of desquamated epithelium or cell detritus which were thought to be produced during the opening formation. Some authors (Murray and Murray 1970; Murray 1973, and many others) report differences in the arrangement of pore components in the taste buds of circumvallate and fungiform papillae. They describe the presence of microvilli in pores of the taste buds of circumvallate papillae and the absence of them in the taste buds of fungiform papillae. None of our specimens had any microvilli in the gustatory pores, which may be the result of fixation or further processing used in this study.

The light round bodies found on the surface of lingual mucosa in foetal sheep and pigs can be taken for lymphocytes passing into the oral cavity from the amniotic fluid. These structures were not investigated in detail.

The results of morphogenic studies under the light microscope (Ti chý $1991 \mathrm{a}, \mathrm{b}$ ) suggest that the circumvallate papilla is commenced at 44 days and attains its typical appearance by day 64 in utero ( Tich ý $1991 \mathrm{a}$ ). The scanning electron microscopic observations showed that in the 68-day-old porcine foetus the circumvallate papillae had a characteristic structure with a highly uneven surface. The rough appearance of the dorsal surface may be a residue of the composite anlage of the papilla found and described earlier ( $T$ ichý 1991 a). In addition, the anlages of fungiform papillae were found in this period. From this it appears that the papillae bearing sensory receptors are formed earlier than those having only mechanical functions. The filiform papillae most probably arise from irregular ridgelike elevations covering the remaining surface of the dorsum linguae, as seen on the porcine tongue at 92 days.

The process of keratinization of surface epithelial cells and their subsequent 
desquamation was evident on the lingual mucosa in the porcine foetus as early as at 68 days. It occurred on the fungiform and circumvallate papillae which both had been differentiated in shape. The surface epithelium also included areas of eroded "primitive" epithelium which was gradually degraded and replaced with the definitive epithelium, as described earlier ( Tich ý 1991 a). A different appearance of the epithelium in different regions suggests an irregular course of maturation in these areas of the lingual mucosa.

Variations in the intensity and degree of keratinization were distinct particularly on the filiform papillae of the tongue in the 92-day-old porcine foetus. The rostral surface of the papillae was covered with a thicker keratinized layer than was seen on the caudal surface. In the filiform papillae studied in the pig and the dog, the cells of the anterior surfaces have shown the presence of soft keratin while the posterior parts have contained thin layers of non-nucleated cells with hard keratin (Boshell et al. 1980; Singh et al. 1980). Iida et al. (1985) have demonstrated a closer connection between cells in the posterior part than those in the anterior surface, which they relate to the necessity of fast replacement of cells lost by a mechanical action of food and other processes. It can be speculated that the thick layer of keratinized cells found on the rostral surfaces of filiform papillae in the foetus is the future mechanically resistant part of the papilla.

Gustatory pores were seen on the dorsal surface of circumvallate papillae only occasionally. The most frequent occurrence was recorded at the border of the dorsal surface and the papillary wall. These findings are in agreement with those made with the use of light microscopy (Tichý $1991 \mathrm{a}, \mathrm{b}$ ). Similarly to the ovine foetus, the pores of the taste buds were identical on both the circumvallate and the fungiform papillae of the porcine foetal tongue observed by scanning electron microscopy. This evidence is contradictory to the results of some authors who report differences in the structure of taste buds between these two types of papillae (Murray and Murray 1970, and others). They describe the presence of microvilli associated with the sensory cells of taste buds on the circumvallate papilla and their absence on the fungiform one. The openings of gustatory pores on the lingual papillae of porcine foetuses were found either in the middle of the flat keratinized intact epithelial cell or, similarly to the ovine foetus, under the desquamated epithelium. This can be explained by the fact that the former developed at an earlier stage and thus were able to repare the epithelium at the site of opening while the latter possessed characteristics of a newly-formed gustatory pore. This could be documented by a higher frequency of pores opening through intact epithelium in the 92-day-old porcine foetus as compared to that at age of 68 days. On the other hand, it is plausible to suggest that the two kinds of opening are due to a continuous exchange of keratinized cells in the surface epithelium.

\section{Conclusions}

The paper describes the selected stages of morphogenesis in several types of lingual papillae of ovine and porcine foetuses. Special attention was given to the differentiation of epithelium of the lingual mucosa and to the occurrence of gustatory pores in the epithelium of circumvallate and fungiform papillae.

Our results can be summarized as follows:

1. The first papillae developing on the dorsum linguae were circumvallate and fungiform papillae. The other papillary types were formed later.

2. The morphogenesis of circumvallate and fungiform papillae in the pig was 
completed by day 92 of intrauterine development. In the sheep the filiform papillae continued to differentiate till after day 126.

3. The epithelium of lingual mucosa first attained its final appearance on circumvallate and fungiform papillae.

4. The process of keratinization and the subsequeent desquamation of superficial epithelium of the lingual mucosa was more marked in the pig than in the sheep. 5. In the porcine foetus at 92 days, the layer of keratinized cells differed in thickness between the rostral and the caudal surfaces of the filiform papilla. The difference was not recorded in the ovine foetus at the corresponding stage of development.

6. The gustatory pores opened onto the mucosal surface either under the desquamated epithelium or by one in the middle of an intact keratinized cell. The latter was most frequently observed in the 92-day-old porcine foetus.

7. The microvilli of sensory cells of taste buds were not found in either the circumvallate or the fungiform papillae in the two species studied.

\section{Morfogeneze vybraných papil jazyka ovce a prasete $v$ rastrovacím elektronovém mikroskopu}

Na odebraných vzorcích jazyka fetů ovce ve stáŕi 70 a 126 dnů a jazyka fetů prasete 68 a 92 dnů po koncepci byl sledován postup morfogeneze hrazených, houbovitých a mechanických papil. Pozornost byla současně věnována stupni diferenciace epitelu sliznice jazyka, intenzitě keratinizace povrchových vrstev epitelií u různých typů tvořících se papil a lokalizaci a utváření chutových pórů na papilách hrazených a houbovitých.

Papily hrazené a houbovité jsou u obou sledovaných druhů vytvořeny dřive než papily ostatních typů. Definitivní podobu nabývá epitel nejprve na papilách hrazených a houbovitých. Keratinizace epitelových buněk sliznice jazyka je u prasete výraznější než u ovce.

Lokalizace chutových pórů na hrazené a houbovité papile je obdobná u ovce i prasete. Rozdíly nejsou ani ve vzhledu pórů u chutových pohárků uložených $\mathrm{v}$ epitelu papily hrazené a papily houbovité.

\section{Морфогенез некоторых сосочков языка овец и свиней в растровом электронном микроскопе}

На полученных образцах языка плода овец в возрасте 70 и 126 суток и языка плода свиней 68 и 92 суток после оплодотворения исследовали процесс морфогенеза желобоватых, грибовидных и нитевидных сосочков. Одновременно уделяли внимание степени дифференциации эпителия слизистой языка, интенсивности ороговения поверхностных слоев эпителей у разных типов образующихся сосочков, а также место и формирование вкусовых пор на желобоватых и грибовидных сосочках.

Желобоватые и грибовидные сосочки у обоих исследуемых видов возникают раньше сосочков остальных типов. Окончательный вид принимает эпителий сначала на желобоватых и грибовидных сосочках. Ороговение клеток эпителия слизистой языка является у свиней более выразительным чем у овец.

Месторасположение вкусовых пор на желобоватом и грибовидном 
сосочках у овец и свиней аналогично. Нет также разницы во внешнем виде пор вкусовых сосочков, расположенных в эпителии желобавотого и грибовидного сосочков.

\section{References}

BANKS, W. J.: Applied veterinary histology. Williams and Wilkins, Baltimore, London, 1981: $374-376$

BARATZ, R. S. - FARBMAN, A. I.: Morphogenesis of rat lingual filiform papillae. Am. J. Anat., . 143, 1975: 283-302

BOSHELL, J. L.-SINGH, B. B. - BREWER, P. D.: Histological and ultrastructural observations of eosinophilic keratohyalin granules in filiform papillae of pig tongue. Acta anat. 108, 1980: $295-300$

BOSHELL, J. L.-WILBORN, W. H.-SINGH, B. B.: Filiform papillae of cat tongue. Acta anat., 114, 1982: 97-105

CORMACK, D. H.: Introduction to Histology. J. B. Lippincott Company Philadelphia, London, New York, 1984: 287-289

EVANS, H. E. - SNACK, W. O.: Prenatal development of domestic laboratory mammals. Growth curves, external features and selected references. Anat., Histol., Embryol. (Zbl. Vet. Med. C) 2, 1973: $11-45$

FARBMAN, A. I.: The dual pattern of keratinization in filiform papillae on rat tongue. J. Anat., 106, 1970: 233-242

HOFER, H. O.: Microscopic anatomy of the apical part of the tongue of Lemur fulvus (primates). Gegenbaurs morph. Jb., 127, 1981: 343-363

HUME, W. J.-POTTEN, C. S.: The ordered columnar structure of mouse filiform papilae. J. Cell Sci., 22, 1976: 149-160

IIDA, M.-YOSHIOKA, I.-MUTO, H.: Three-dimensional and surface structures of rat filiform papillae. Acta anat., 121, 1985: 237-244

KRÖLLING, O.-GRUA, H.: Lehrbuch der Histologie und vergleichenden mikroskopischen Anatomie der Haustiere. Paul Parey, Berlin und Hamburg, 1960: 195-204

MATRAVERS, J. M.-HEANEY, T. G.-APPLETON, J.: Computer analysis of the surface ultrastructural features of porcine oral mucosa. Archs. oral Biol., 27, 1982: 481-485

MILLES, A. E. W.: The behaviour of the dorsal mucosa of the rat tongue in organ culture. J. Anat., 117, 1974: $541-552$

MURRAY, R. G.: The structure of taste buds. In: Ultrastructure of sensory organ, vol. 1, Friedman, ed. Amsterdam: North Holland, 1973: 1-81

MURRAY, R. G.-MURRAY, A.: The anatomy and ultrastructure of taste endings. In: (ed. by) G. E. W. Wolstenholme and J. Knight: Taste and smell in vertebrates. London, J. and A. Churchil, 1970: 3-30

NAIR, P. N. R. - SCHRODEDER, H. E.: Variation and density of microplications in superficial cells of the normal oral lining mucosa in the monkey, Macacus fascicularis. Archs. oral Biol., 26, $1981: 837-843$

ROOSS, M. H.-REITH, E. J.: Histology a Text and Atlas. Harper Row, Publishers, J. B. Lippincott company, New York, Cambridge, Philadelphia, San Francisco, London, 1985: 400-403

SINGH, B. B.-BAKER, R.-BOSHELL, J.-McKINNEY, R. V.: Observations on the eosinophilic granules in the dorsal papillae of the dog tongue. J. oral Path., 9, 1980: 99-105

SINGH, B. B.-McKINNEY, R. V.-ALLEN, E.-BAKER, R.-KOLAS, S.: Observations on keratohyaline and eosinophilic bodies of tongue epithelia from hamster, rat, mouse, guinea pig and dog. Anat. Rec. 178, 1974: 464

SMOLICH, A. - MICHEL, G.: Mikroskopische Anatomie der Haustiere. VEB Gustav Fischer Verlag Jena, 1985: pp. 91-94, and pp. 363-364

STENSAAS, L. J.: The fine structure of fungiform papillae and epithelium of the tongue of the South American toad, Calyptocephalella gayi. Am. J. Anat., 131, 1971: 443-452

TAKAGI, T. -SAITO, H.-ASO, N.: Mechanism on the differentiation of microridges. Scanning electron microscopy of the surface structures of epithelial cells of the developing human tongue (in Japanese). Jap. J. oral Biol., 18, 1976: 418-434

TICHYY, F.: The morphogenesis of circumvallate papillae and the differentiation of taste buds in the pig at 41 to 64 days of prenatal develcpment. Acta vet. Brno, 60, 1991a: 99-100

TICHY, F.: The morphogenesis of circumvallate papillae and the differentiation of taste buds in the porcine foetus from day 76 till birth and in the adult pig. Acta vet. Brno, 60, 1991 : :307-315

TICHÝ, F.- CERNÝ, H.: The morphogenesis of circumvallate papillae and differentiation of taste buds in sheep ontogeny. Acta vet. Brno, 56, 1987: 261-274 
Plate I.

Tichý F.: The Morphogenesis ... pp. 3-10.

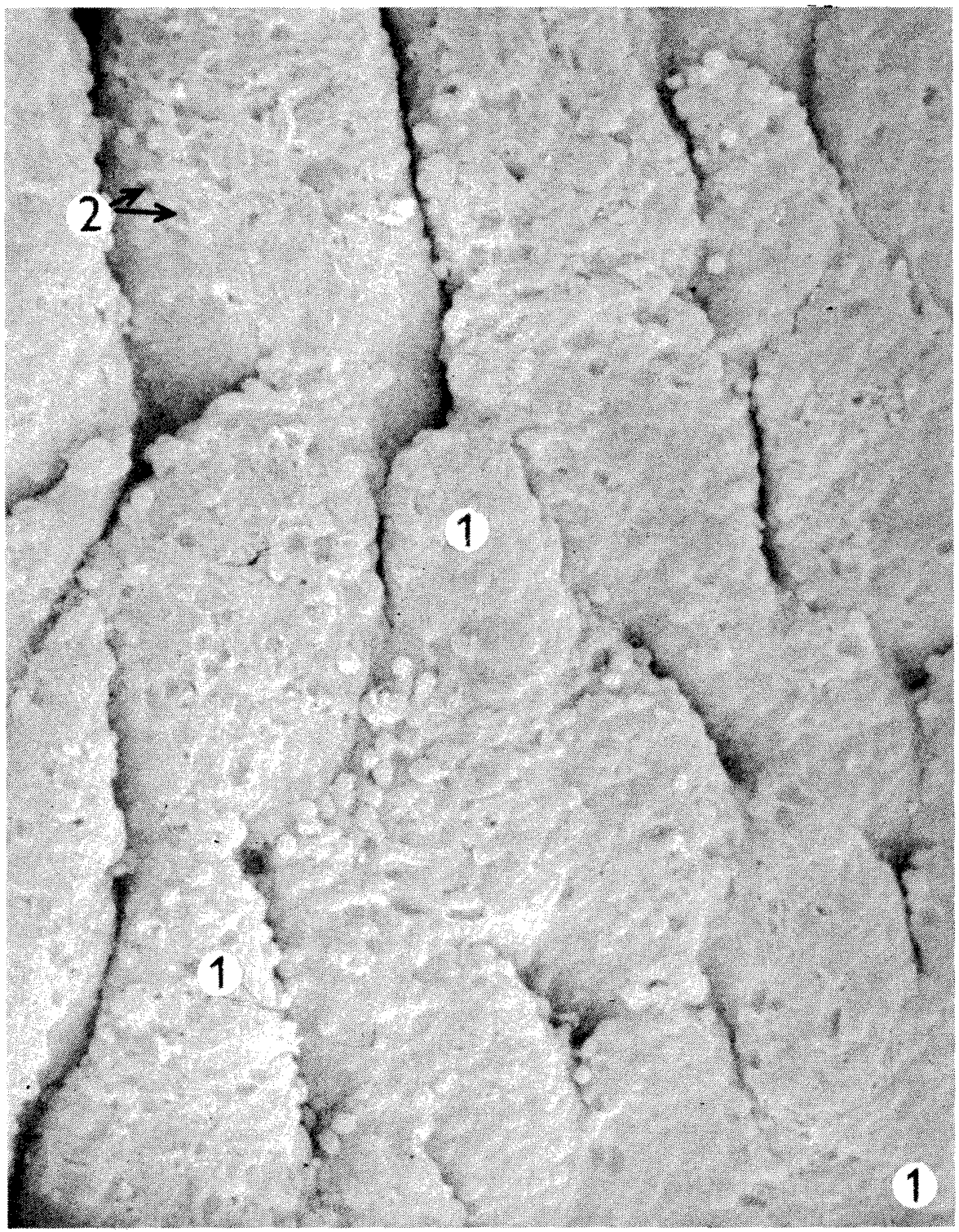

Fig. 1: The lingual surface in the ovine foetus at 70 days. Irregular anlages of lingual papillae (1), desquamation of epithelial cells (2). Scanning electron microscopy (SEM); $\times 165$. 
Plate II.



Fig. 2: A section of the lingual mucosa in the ovine foetus at 126 days. Circumvallate papilla with a large vallum (1), atypical spiral circumvallate papilla (2). Anlages of filiform papillae (3). SEM, x 51. 
Plate III.

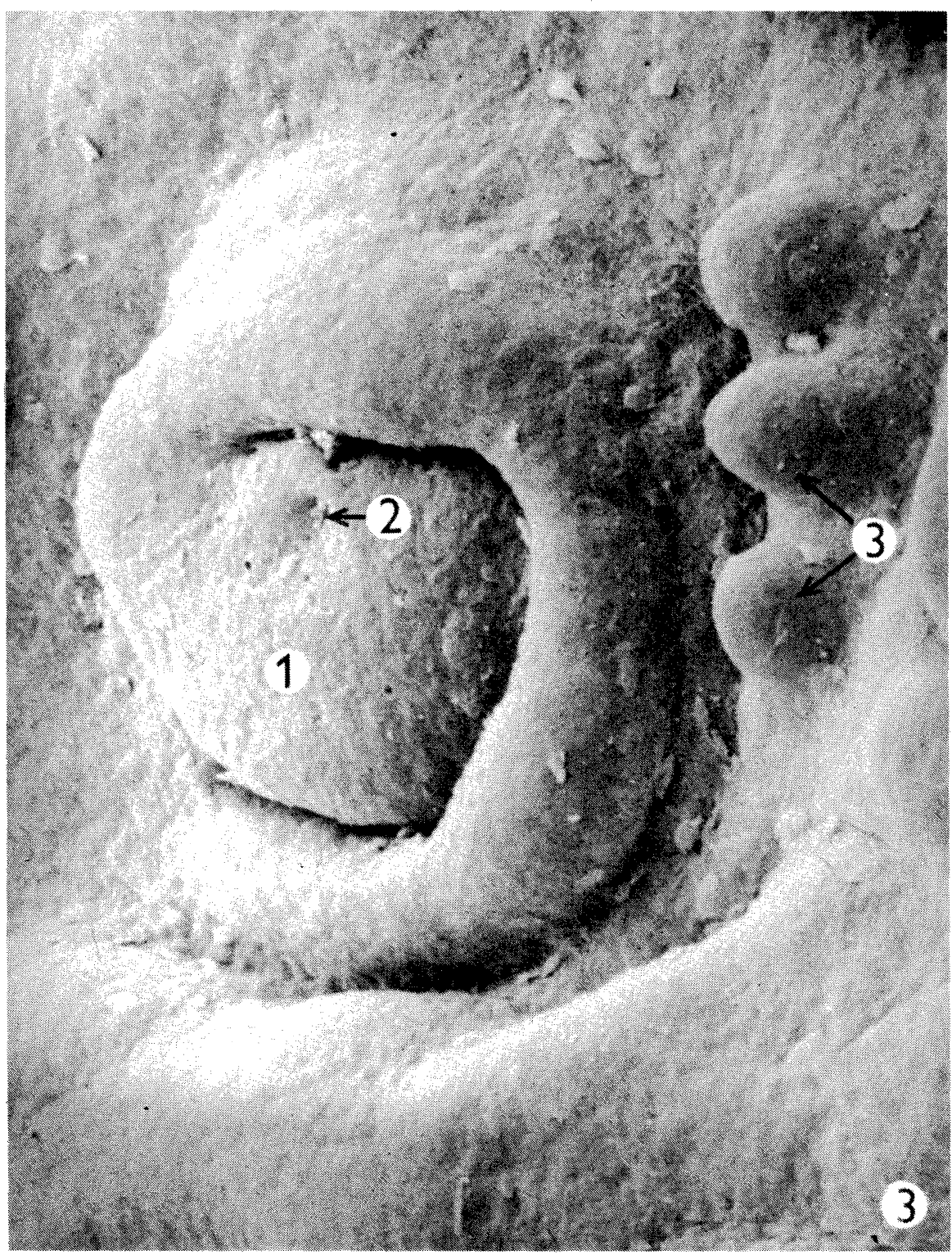

Fig. 3: A detail of Fig. 2. Circumvallate papilla (1) with a taste bud (2) on the dorsal surface. Anlages of filiform papillae (3). SEM, $\times 120$. 
Plate IV.

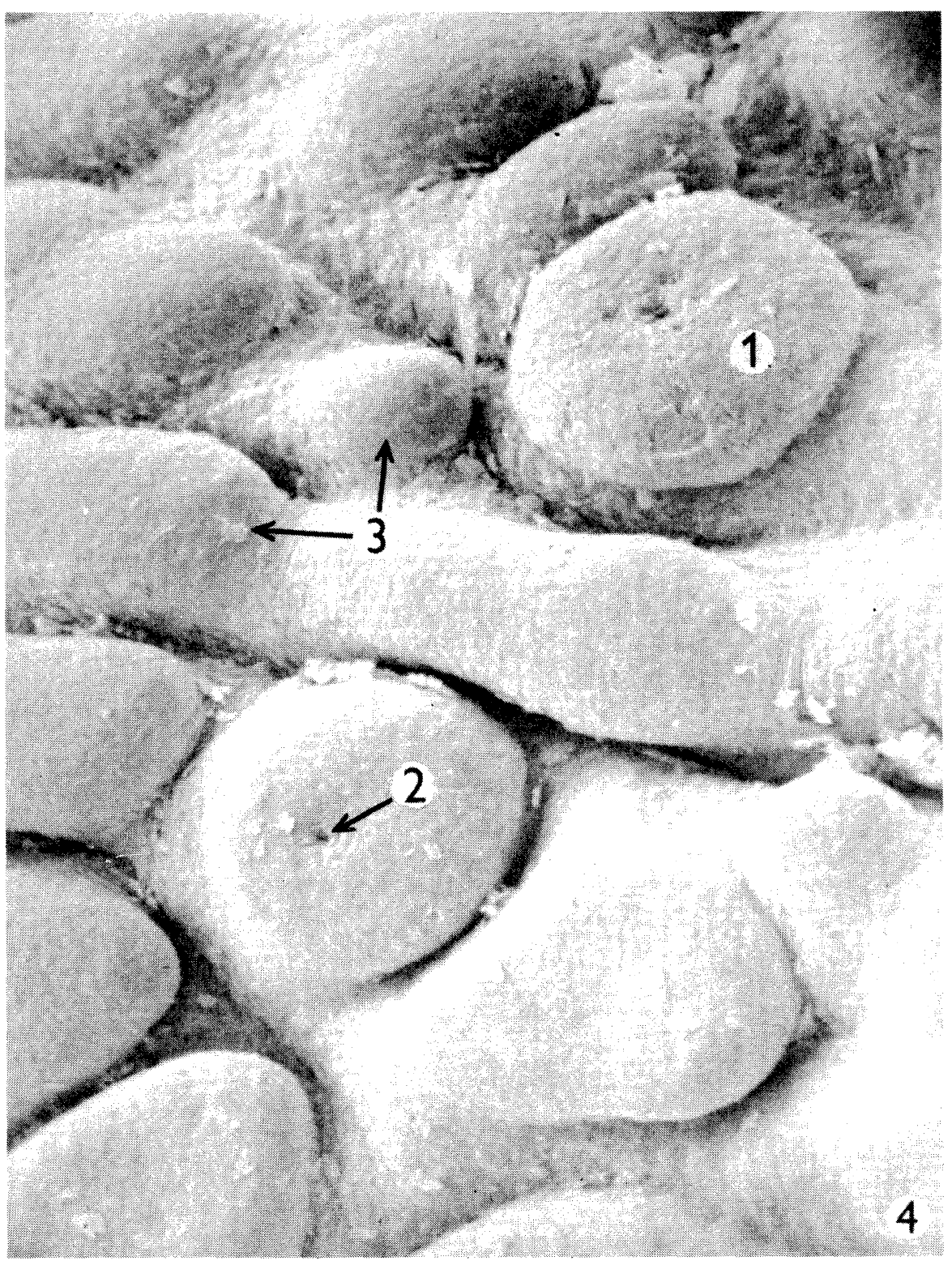

Fig. 4: The dorsum linguae in a 126-day-old ovine foetus. Fungiform papillae typical in shape (1), gustatory pores on their surfaces (2). Differentiating filiform papillae (3). SEM, $\times 90$. 
Plate V.

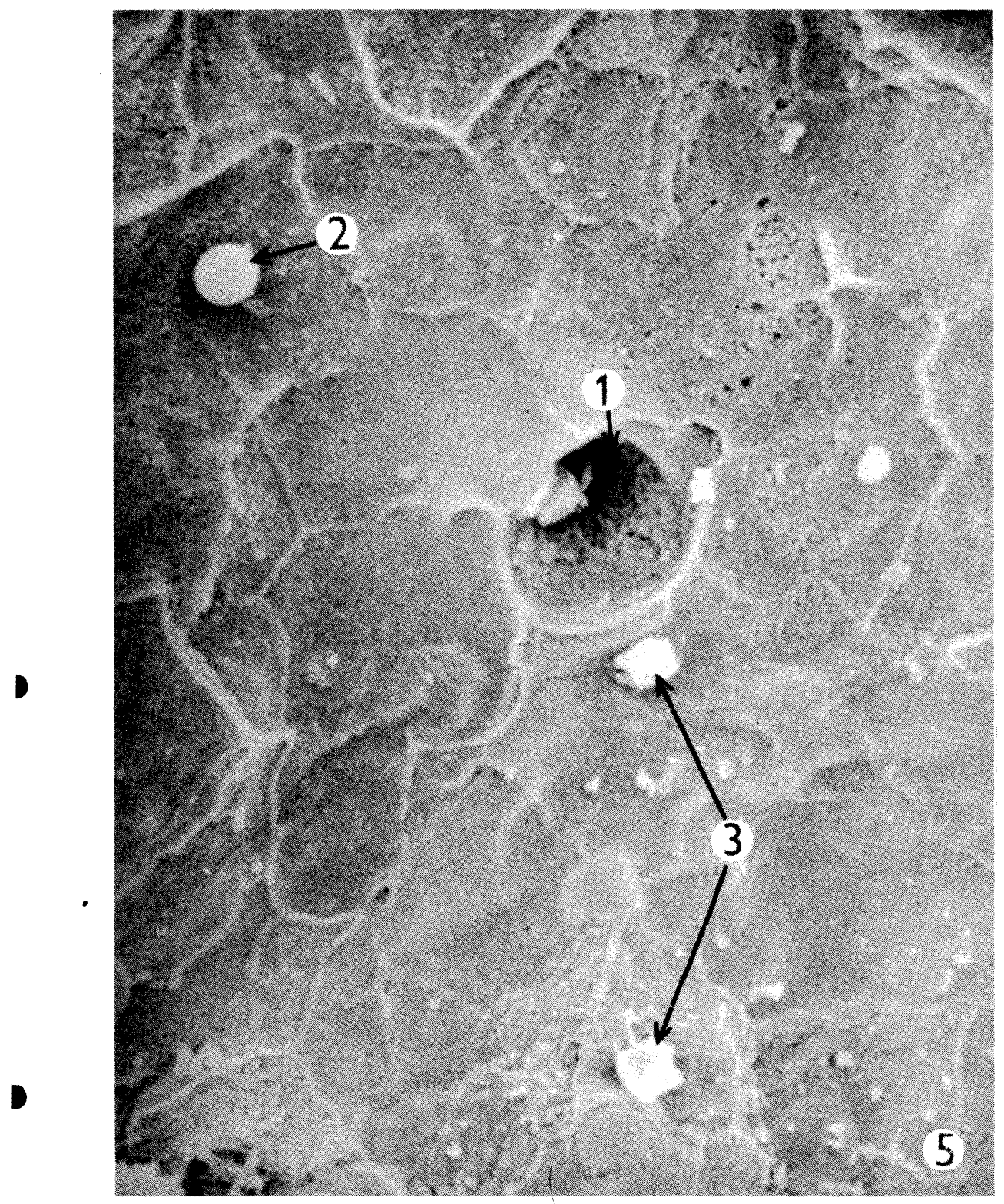

Fig. 5: A detail of the gustatory pore (1) on a circumvallate papilla in the ovine foetus at 126 days. Round body on the epithelial surface (2), detritus (3). SEM, $\times 2325$. 
Plate VI.

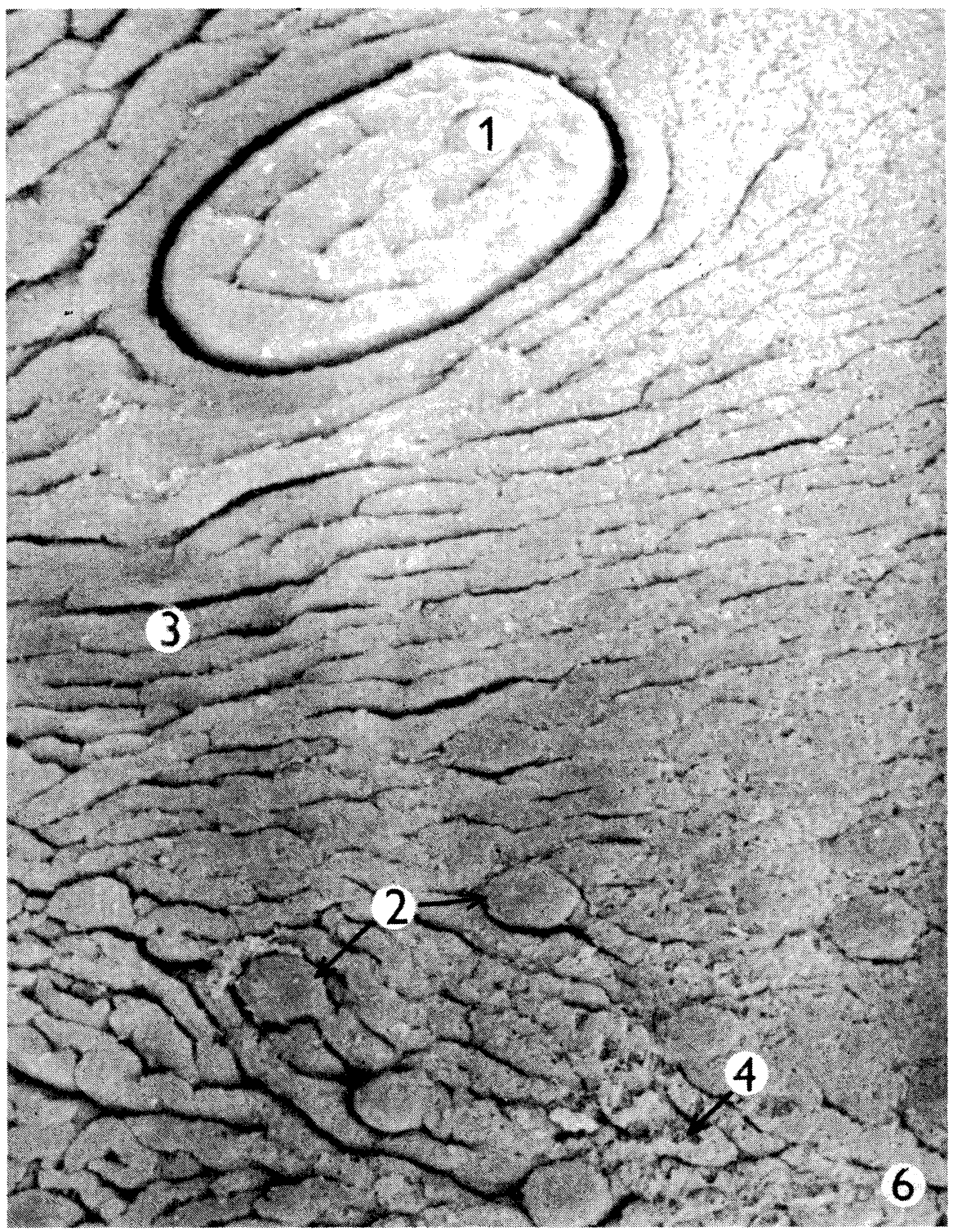

Fig. 6: The lingual surface of the 68-day-old porcine foetus. Circumvallate papilla (1) surrounded by numerous anlages of fungiform papillae (2). Undifferentiated ridges are probably the anlages of other types of lingual papillae (3). Mucosal surface show marked epithelial erosion (4.) SEM, $\times 47$. 
Plate VII.

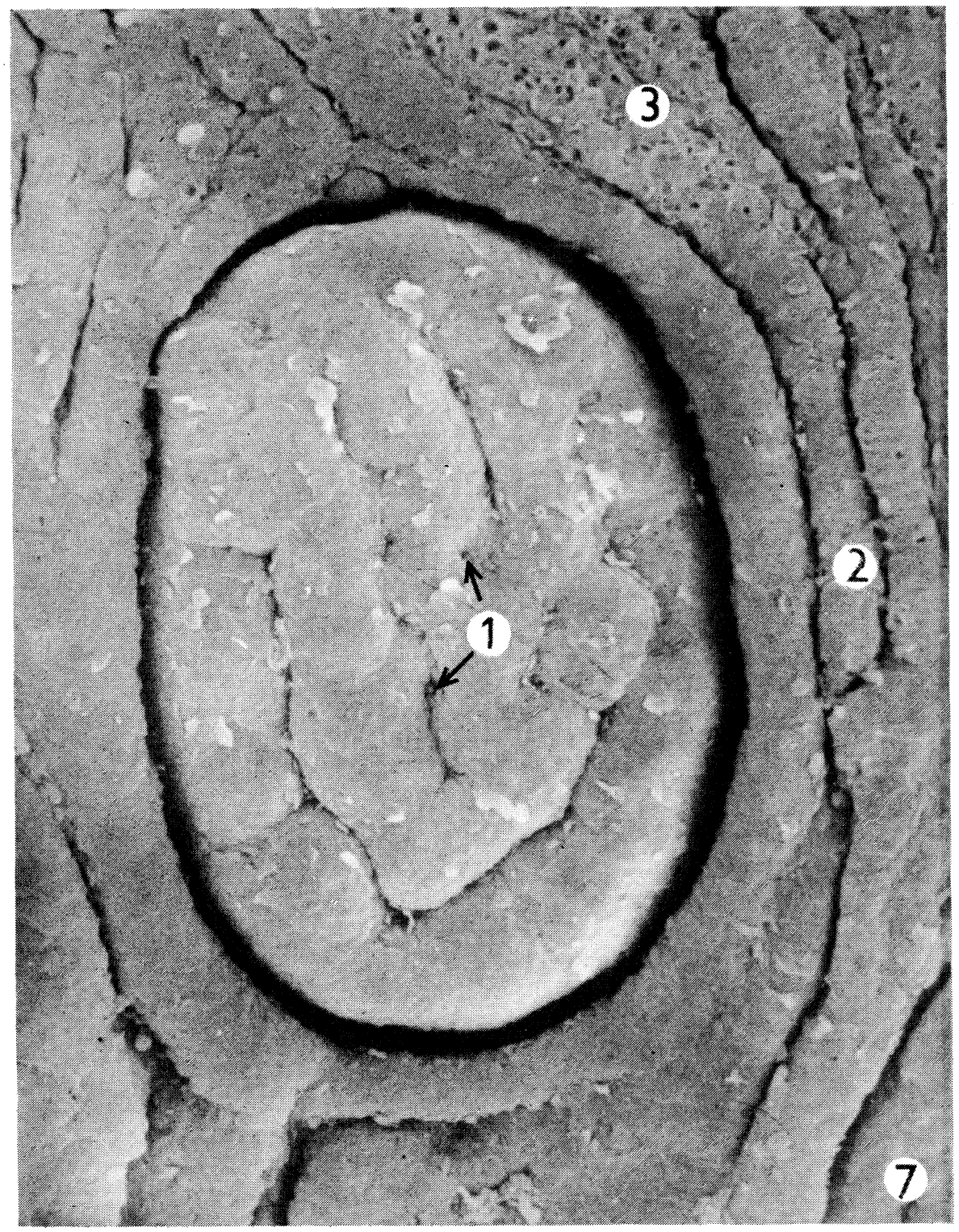

Fig. 7: A detail of the circumvallate papilla in Fig. 6. Gustatory pores on the dorsal surface (1), ridges on the epithelial surface (2), eroded epithelium (3). SEM, $\times 94$. 
Plate VIII.

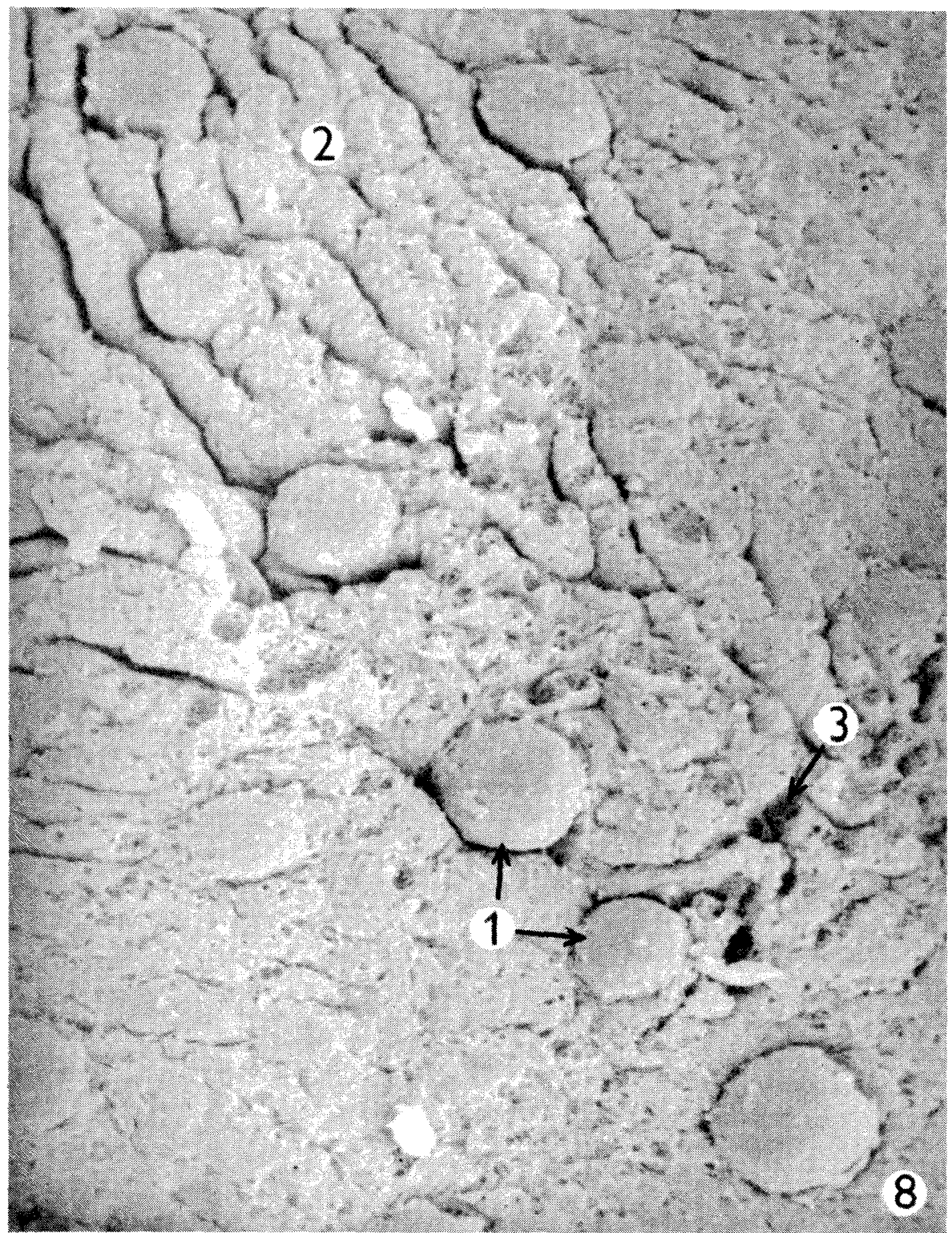

Fig. 8: A group of fungiform papillae (1) on the dorsum linguae in the 68-day-old porcine foetus. Ridgelike elevations (2), areas of eroded epithelium (3). SEM, $\times 78$. 
Plate IX.



Fig. 9: A detailed view of the edge of the circumvallate papilla in Fig. 6. Encircling furrow (1), gustatory pores at the border of the wall and the dorsal surface (2). Desquamation of flat epithelial cells (3). SEM, x 1200. 
Plate X.

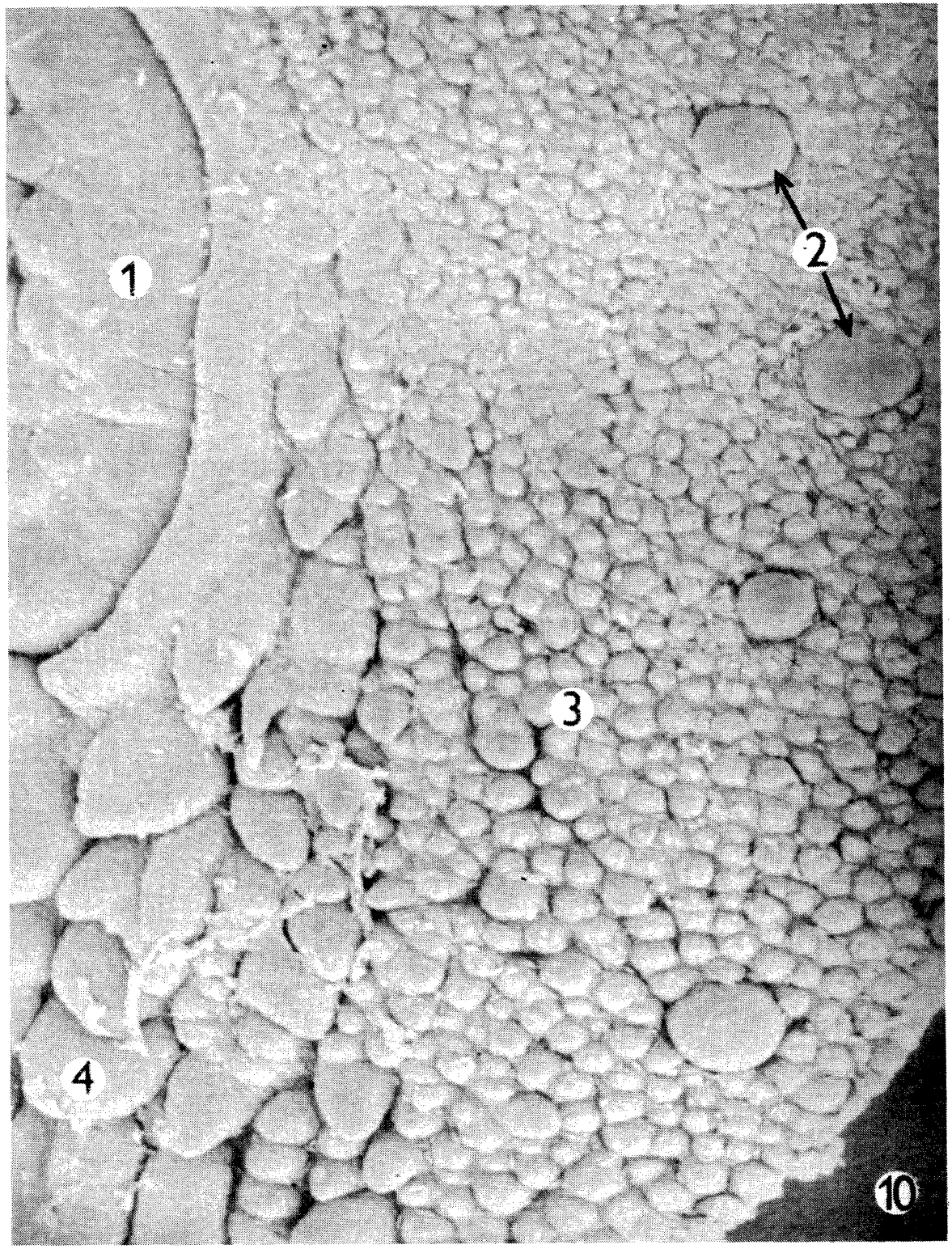

Fig. 10: The dorsum linguae in the porcine foetus at 92 days. Circumvallate papilla (1), fungiform papillae (2), numerous filiform papillae (3), groups of undifferentiated papillae (4). SEM, $\times 47$. 
Plate XI.

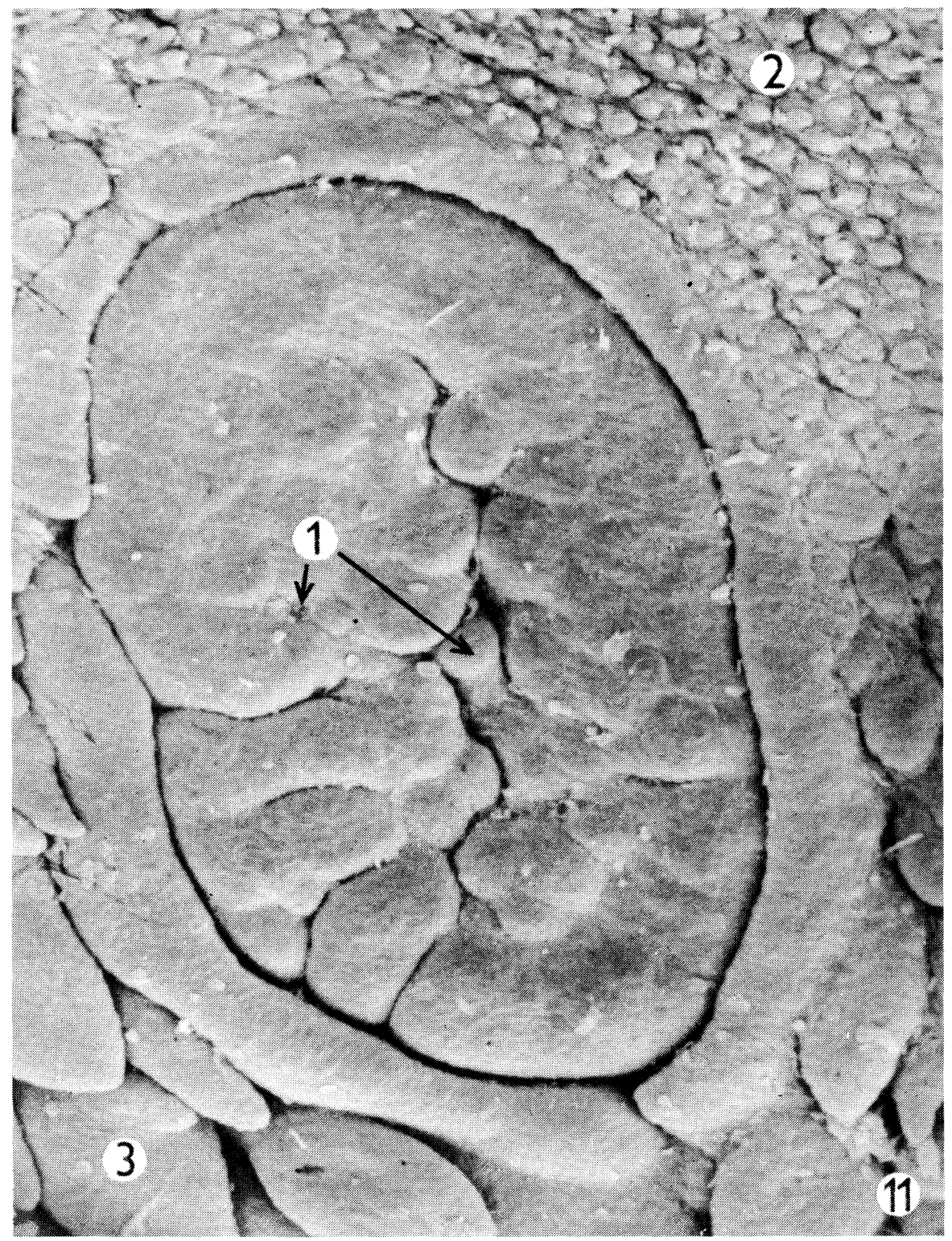

Fig. 11: A circumvallate papilla in the 92-day-old porcine foetus. Its dorsal surface shows occasional gustatory pores (1), numerous filiform papillae (2), a group of undifferentiated papillae (3). SEM, × 60 . 
Plate XII.

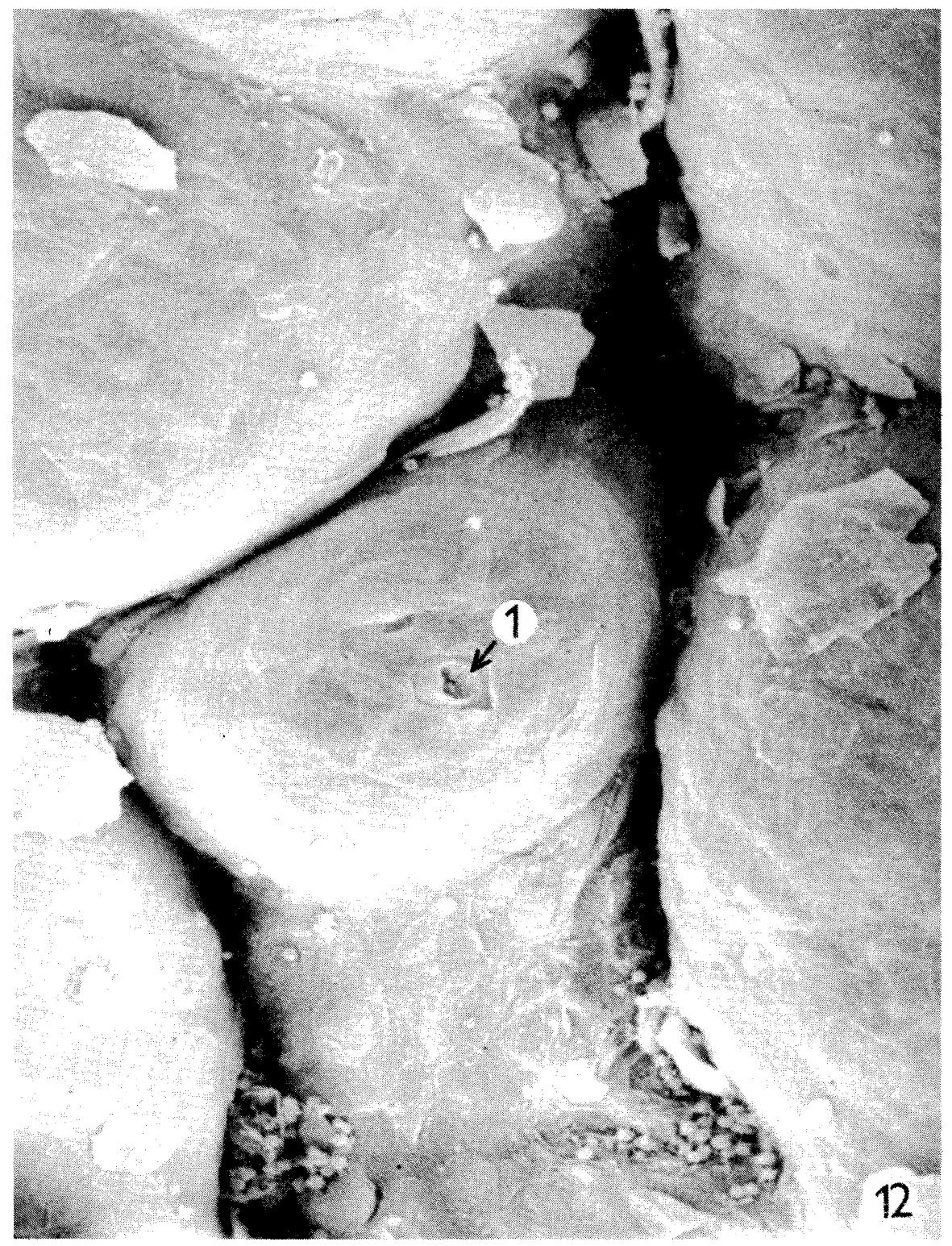

Fig. 12: A detail of the rough dorsal surface of the circumvallate papilla in Fig. 11. Gustatory pore (1) under a desquamated epithelial cell. SEM, $\times 473$. 


\section{Plate XIII.}

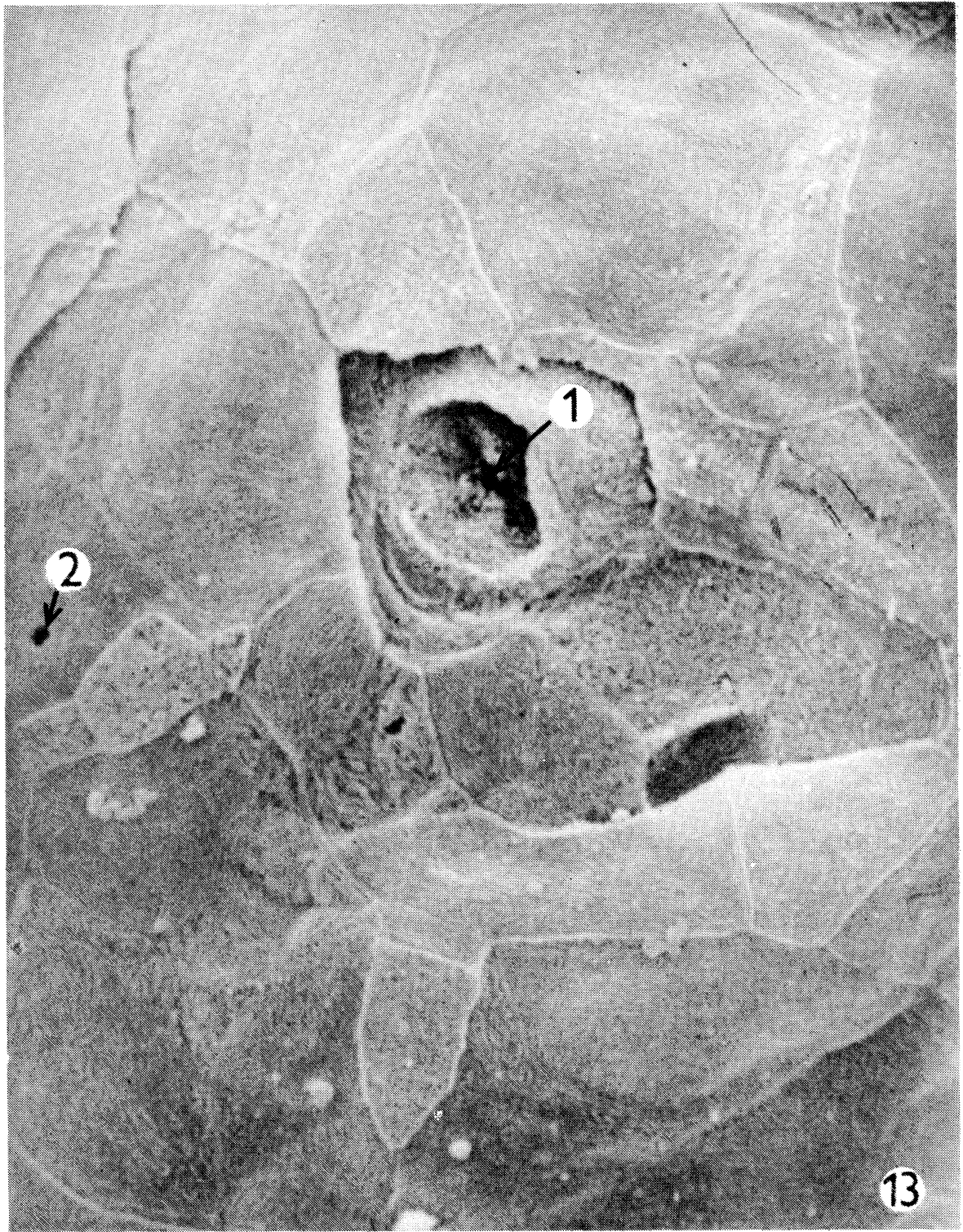

Fig. 13: The opening of the gustatory pore in Fig. 12. Intact gustatory pore (2). SEM, x 2325. 
Plate XIV.

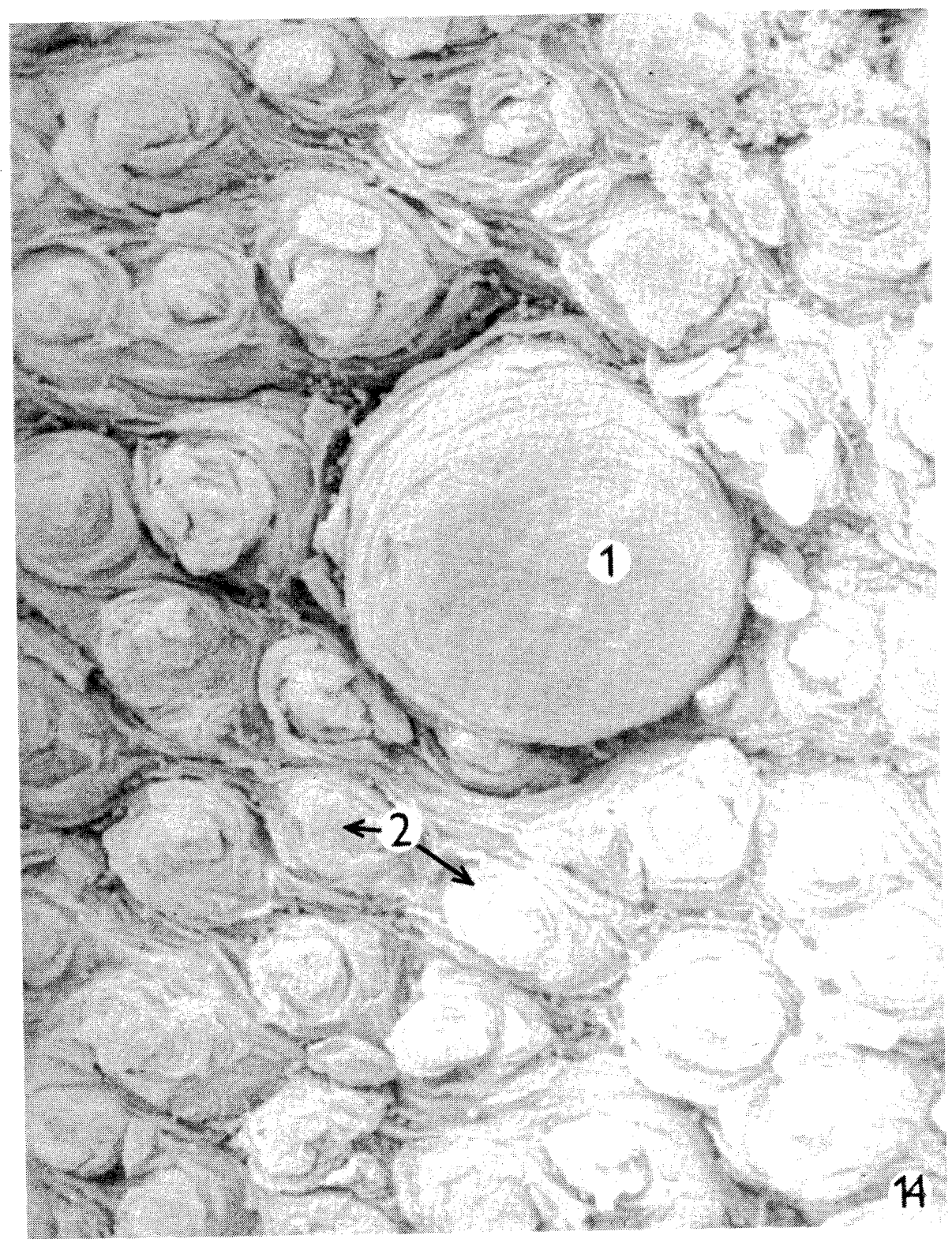

Fig. 14: A fungiform papilla (1) in the porcine foetus at 92 days. Numerous filiform papillae (2) in its surroundings. SEM, $\times 315$. 